\title{
The Induction of Proteolysis in Purulent Sputum by Iodides *
}

\author{
Jack Lieberman and Nathaniel B. Kurnick \\ (From the Veterans Administration Hospital, Long Beach, and the Department of Medicine, \\ the University of California Center for Medical Sciences at Los Angeles, Calif.)
}

Iodide, in the form of potassium or sodium iodide, is widely used as an expectorant for patients with viscid sputum. The iodides are thought to act by increasing the volume of aqueous secretions from bronchial glands (1). This mechanism for the effect of iodides probably plays an important role, but an additional mechanism whereby iodides may act to thin viscid respiratory secretions was demonstrated during a study of the proteolytic enzyme systems of purulent sputum.

Purulent sputum contains a number of proteolytic enzymes, probably derived from leukocytes $(2-4)$. These proteases, however, are ineffective in causing hydrolysis of the native protein in purulent sputum and do not appear to contribute significantly to the spontaneous liquefaction of these purulent secretions. On the other hand, these intrinsic proteases are capable of causing proteolysis after the exudative protein is separated from deoxyribonucleic acid (DNA) by the action of deoxyribonuclease (DNase) or high concentrations of sodium chloride (5).

During these studies an attempt was made to evaluate the effectiveness of various salts for inducing proteolysis in purulent sputum, ostensibly by liberating protein from nucleoprotein complexes. Sodium iodide was found to induce more rapid proteolysis than any other salt tested, but we were able to demonstrate that the mechanism did not primarily involve the dissolution of nucleoprotein complexes. In addition, iodinated tyrosine and thyronine compounds were found to

* Submitted for publication October 9, 1963; accepted June 15, 1964.

Presented in part before the Western Section of the American-Federation for Clinical Research, Carmel, Calif., January 30, 1963.

Aided by a grant from the California Research and Medical Education Fund of the Tuberculosis \& Health Association of California and grants HE1880 and CA-0382-07 from the National Heart and National Cancer Institutes, U. S. Public Health Service. have even greater proteolysis-inducing activities than inorganic iodide.

\section{Methods}

Source of sputum specimens. Purulent sputa were obtained from 17 patients with cystic fibrosis and from 22 with other types of pulmonary problems (Table VIII). Two specimens of pus were obtained and studied in a similar fashion. The sputa were collected in glass jars kept in the patients' home freezers at approximately $-10^{\circ} \mathrm{C}$ over a 2 - to 5 -day period and then were kept frozen at $-20^{\circ} \mathrm{C}$ up to 3 weeks. Sputa collected from hospitalized patients were frozen after a 4-hour collection period.

Preparation of sputum homogenates. Individual sputum specimens were homogenized in distilled water with a Potter-Elvehjem homogenizer to form $10 \%$ (wet weight to volume) homogenates. The $10 \%$ homogenates were diluted further in some experiments. In certain experiments fresh sediments were prepared by centrifugation 1 of the $10 \%$ aqueous sputum homogenates at $30,000 \mathrm{~g} \times 15$ minutes at $0^{\circ} \mathrm{C}$. The supernatant fluids were decanted, and the sediments were washed where indicated by resuspension to the initial volume followed by recentrifugation.

Assay of proteolysis. Proteolysis was determined routinely by measuring the liberation of trichloroacetic acid (TCA)-soluble protein fragments by the FolinCiocalteu (F-C) test. The $10 \%$ homogenate of sputum and the reagent whose proteolysis-stimulating effect was being tested were both adjusted to the appropriate $\mathrm{pH}$ (see below) with $0.1 \mathrm{~N} \mathrm{NaOH}$ or $\mathrm{HCl}$, before being mixed in equal volumes. The mixture was then incubated in duplicate in a $37^{\circ} \mathrm{C}$ water bath. Two-ml samples were removed at suitable intervals, added to $4.0 \mathrm{ml}$ $16 \% \mathrm{TCA}$, and centrifuged at $30,000 \mathrm{~g}$ for 15 minutes. The supernatant fractions $(2.0 \mathrm{ml})$ were mixed with 4.0 $\mathrm{ml}$ of $1 \mathrm{~N} \mathrm{NaOH}$ in colorimetric cuvettes, and $1.0 \mathrm{ml}$ of F-C reagent (diluted 1:3 with distilled water) was added to each cuvette and mixed immediately. Exactly 5 minutes later the absorbance was measured on a Coleman Junior spectrophotometer at $675 \mathrm{~m} \mu$ against a reagent blank. Proteolysis is expressed as the optical density developed in a given period of incubation. A similar proteolytic assay utilizing F-C reagent was used with

${ }^{1}$ Servall refrigerated automatic centrifuge, SM-24 rotor. 
extraneous protein substrates such as casein, hemoglobin, gelatin, and albumin.

Three other methods for detecting proteolysis were utilized to confirm the observation of iodide-induced proteolysis. The first of these methods assayed the tyrosine content of the TCA-insoluble sediment, instead of the supernatant fluid, with the F-C reagent as follows: After centrifugation of the TCA mixture, the sediment was washed once with $10 \% \mathrm{TCA}$, then dissolved in a volume of $1 \mathrm{~N} \mathrm{NaOH}$ equal to that of the initial TCA mixture. Two $\mathrm{ml}$ of the dissolved sediment was then mixed with $4.0 \mathrm{ml} 1 \mathrm{~N} \mathrm{NaOH}$ and finally with $1.0 \mathrm{ml}$ of the F-C reagent; the absorbance was measured on the spectrophotometer at $675 \mathrm{~m} \mu$ against a reagent blank.

In a second supplementary method of assaying proteolysis, the absorbance of the TCA-supernatant fluid was measured directly with a Beckman DU spectrophotometer at $280 \mathrm{~m} \mu$ against a water blank.

The third supplementary method for assaying proteolysis involved the assay of alpha-amino nitrogen with Ninhydrin according to the method of Moore and Stein (6). A $0.2-\mathrm{ml}$ sample of the TCA-supernatant fluid was mixed with $1.3 \mathrm{ml}$ of $0.1 \mathrm{~N} \mathrm{NaOH}$ (to adjust to $\mathrm{pH} 5.0$ ) and with $2.0 \mathrm{ml}$ of the Ninhydrin solution. The mixture was heated in a boiling water bath for 20 minutes, followed by the addition of $15 \mathrm{ml}$ of diluent (a $50: 50 \mathrm{mix}-$ ture of $n$-propanol with water) and vigorous shaking for 1 minute. The mixture was poured into colorimeter tubes and the absorbance determined against a reagent blank at $570 \mathrm{~m} \mu$ on a Coleman Junior spectrophotometer.

Preparation of iodinated tyrosine and thyronine solutions. The iodinated organic compounds used in this

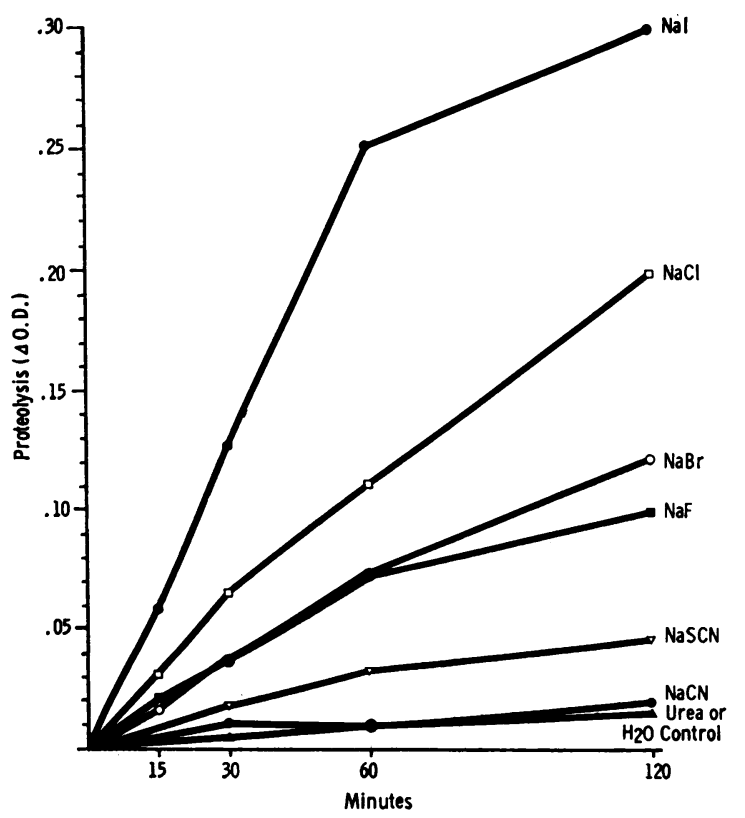

Fig. 1. INFLUENCE OF VARIOUS IONS AND UREA ON PROTEOLYSIS IN PURULENT SPUTUM AT PH 7.5 (CONCENTRATION OF EACH ADDITIVE $=1 \mathrm{M}$ ).

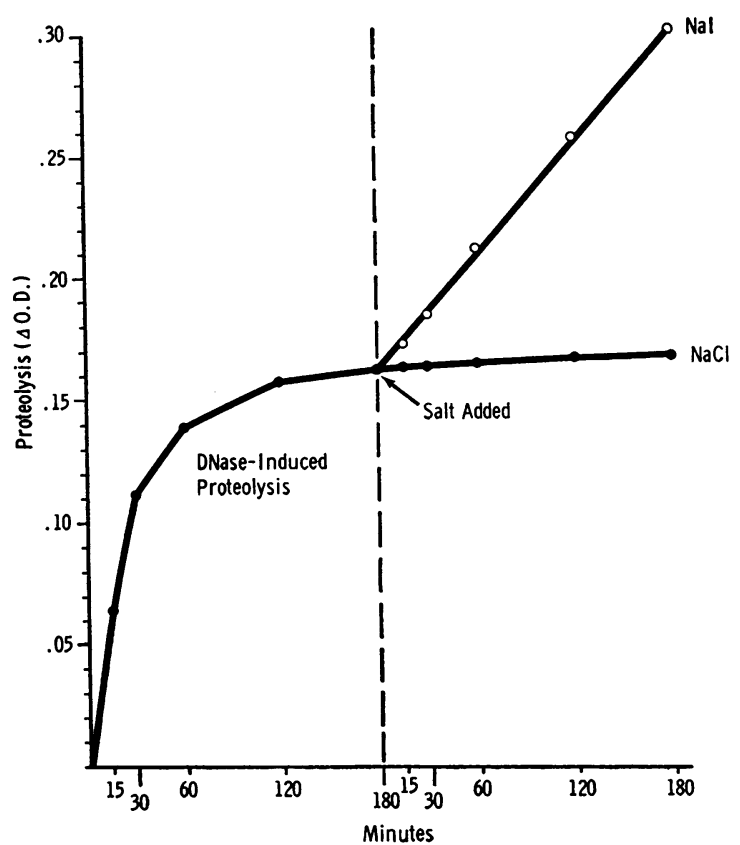

Fig. 2. Additive effects of $1 \mathrm{M}$ NaI oR $\mathrm{NACl}$ on DNASE-INDUCED PROTEOLYSIS IN PURULENT SPUTUM.

study were difficult to dissolve in neutral buffer solutions. The following procedure was used routinely for preparing $25.0 \mathrm{ml}$ of such solutions in $0.05 \mathrm{M}, \mathrm{pH} 7.5$ sodium phosphate buffer. The iodine compound was weighed and then dissolved in $2.0 \mathrm{ml}$ of $0.1 \mathrm{~N} \mathrm{NaOH}$. Fifteen $\mathrm{ml}$ of distilled water and $2.5 \mathrm{ml} 0.5 \mathrm{M}, \mathrm{pH} 7.5$ sodium phosphate buffer were then added, and the mixture was brought to $\mathrm{pH} 7.5$ with $0.1 \mathrm{~N} \mathrm{HCl}$ while being stirred constantly. The volume was adjusted to $25.0 \mathrm{ml}$ with distilled water.

Reagents. Reagent grade chemicals were used. Soybean-trypsin inhibitor ( $5 \times$ crystalline $) ;^{2}$ L-3,5-diiodothyronine and its analogues, L-3,5-diiodotyrosine, D-3,5diiodotyrosine, L-3,5-dibromotyrosine, and tyrosine ${ }^{3}$ L-3,3',5-triiodothyronine, L-thyroxine, D-thyroxine, L-3monoiodotyrosine, and DL-3,5-diiodothyronine; ${ }^{4}$ deoxyribonuclease $\left(1 \times\right.$ crystallized) $;^{5}$ and trypsin $(2 \times$ crystalline $)^{2}$ were obtained commercially.

\section{Results}

The experimental data to be described were obtained from experiments with individual sputum specimens, but each experiment was repeated with sputa obtained from at least four other individuals. The absolute proteolytic activity varied from pa-

${ }^{2}$ Nutritional Biochemicals Corp., Cleveland, Ohio.

3 Cyclo Chemical Corp., Los Angeles, Calif.

${ }^{4}$ California Corporation for Biochemical Research, Los Angeles, Calif.

5 Worthington Biochemical Corp., Freehold, N. J. 


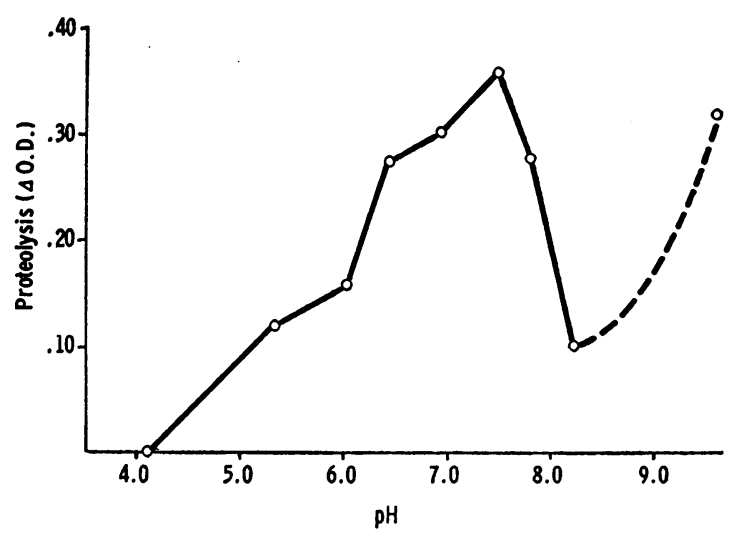

Fig. 3. Optimal pH CURVE fOR PROTEOLYSis INDUCED By $1 \mathrm{M}$ NaI in a homogenate of pURUlent SPUtUm.

tient to patient (4), but the qualitative results described below were characteristic of all specimens examined.

\section{Effect of various electrolytes}

Figure 1 shows the rates of proteolysis at $\mathrm{pH}$ 7.5 in $5 \%$ sputum homogenates in the presence of various $1 \mathrm{M}$ salt solutions or urea or with distilled water as a control. Sodium iodide (or potassium iodide) caused a higher rate of proteolysis than that resulting from any of the other electrolytes tested, although the other halogens, namely, chloride, bromide, and fluoride, also caused some proteolysis. Sodium thiocyanate induced only minimal proteolysis. The effect of sodium cyanide or

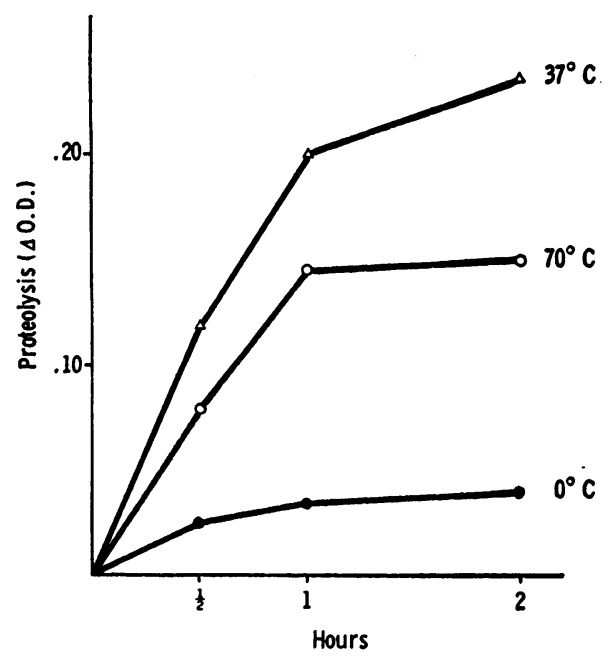

Fig. 4. EFFECT OF TEMPERATURE UPON PROTEOLYSIS INDUCED BY $1 \mathrm{M}$ NAI IN A HOMOGENATE OF PURULENT SPUTUM (0.025 M SODIUM PHOSPhATE BUfFER, PH 7.5). urea was insignificant and did not differ appreciably from the control.

A difference between iodide- and chloride-induced proteolysis was demonstrated by the experiment shown in Figure 2. The proteolysis resulting from the action of DNase (1.0 mg DNase $+5.0 \mathrm{ml}$ sputum homogenate $+5.0 \mathrm{ml} 0.05 \mathrm{M}$ sodium phosphate buffer, $\mathrm{pH} 7.5$ ) appeared to be complete by the end of a 3-hour incubation period (Figure 2). At this time an equal volume of $2 \mathrm{M}$ $\mathrm{NaCl}$ was aded to one portion of the reactant mixture, and $2 \mathrm{M} \mathrm{NaI}$ was added to another portion of the mixture. The addition of $\mathrm{NaCl}$ did not result in further proteolysis, but the addition of $\mathrm{NaI}$ renewed the proteolytic action.

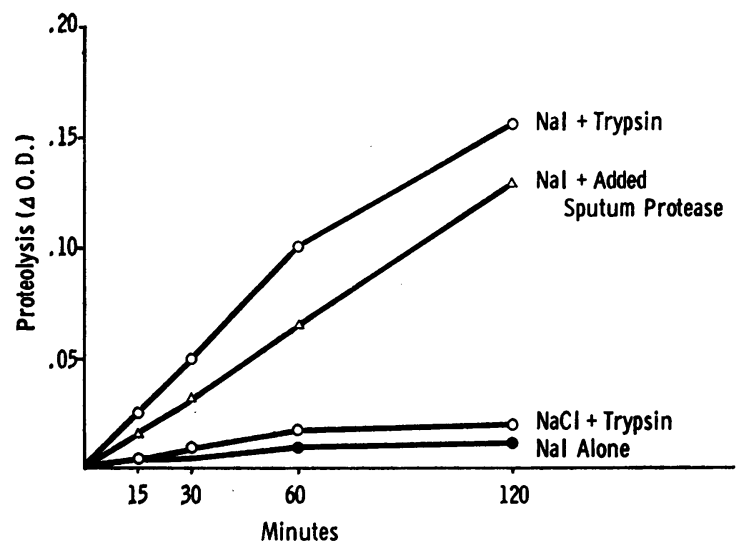

Fig. 5. Influence of $1 \mathrm{M}$ NaI or NaCl on proteolySIS BY TRYPSIN ( 0.2 MG PER ML) OR SPUTUM PROTEASE ( 0.5 ML OF UNHEATED SPUTUM HOMOGENATE PER $5.0 \mathrm{ML}$ ) With $80^{\circ} \mathrm{C}$-heated SPUTUM AS SubStrate $(0.025 \mathrm{M}$ soDiUM PHOSPHATE BUfFER, PH 7.5).

\section{Enzymatic nature of iodide-induced proteolysis}

Optimal $p H$. The proteolytic effect of sodium iodide was studied at the various $\mathrm{pH}$ levels shown in Figure 3. An optimum between $\mathrm{pH} 7.0$ and 7.5 was demonstrated. At $\mathrm{pH}$ values above 9.0 the high electrolyte concentrations caused hydrolysis that is nonenzymatic, as was previously observed with $\mathrm{NaCl}$ (5).

Effect of temperature. Proteolysis was more active at $37^{\circ} \mathrm{C}$ than at $70^{\circ}$ or $0^{\circ} \mathrm{C}$ (Figure 4). The proteolytic reaction could be prevented by boiling the sputum preparation or by heating at $80^{\circ} \mathrm{C}$ for 1 hour before mixing with sodium iodide (Figure 5, bottom curve). The native proteases within purulent sputum were found to be 
completely destroyed by heating at $80^{\circ} \mathrm{C}$ (3). The addition of trypsin or of a small amount of unheated sputum to the heated sputum preparation resulted in active proteolysis in the presence of $1 \mathrm{M}$ sodium iodide, but not with $1 \mathrm{M}$ sodium chloride.

Effect of soybean-trypsin inhibitor. Soybeantrypsin inhibitor (SBTI) has been observed to inhibit a "heat-labile" protease (inactivated at $65^{\circ} \mathrm{C}$ ) in purulent sputum when tested upon a casein substrate, but not to inhibit a "heat-stable" protease (3). A similar result was obtained when sputum protein, instead of casein, was used as substrate. SBTI (2.3 $\mathrm{mg}$ per $\mathrm{ml}$ ) caused $70 \%$ inhibition of iodide-induced proteolysis (1-hour incubation) in an unheated sputum homogenate, but did not significantly inhibit iodide-induced proteolysis of a $65^{\circ} \mathrm{C}$-heated sputum preparation (Table I).

\section{Optimal concentration of sodium iodide}

Various concentrations of sodium iodide were tested with a sputum homogenate to determine the effect of iodide concentration upon the induction of proteolysis. Two types of sputum preparations were used for this experiment: (A) a routine sputum preparation that had not been heated before the experiment and (B) another portion of the same sputum homogenate that had been heated at $65^{\circ} \mathrm{C}$ for 1 hour to destroy the "heat-labile" protease. As can be seen in Figure 6, iodide caused more proteolysis in the unheated sputum during

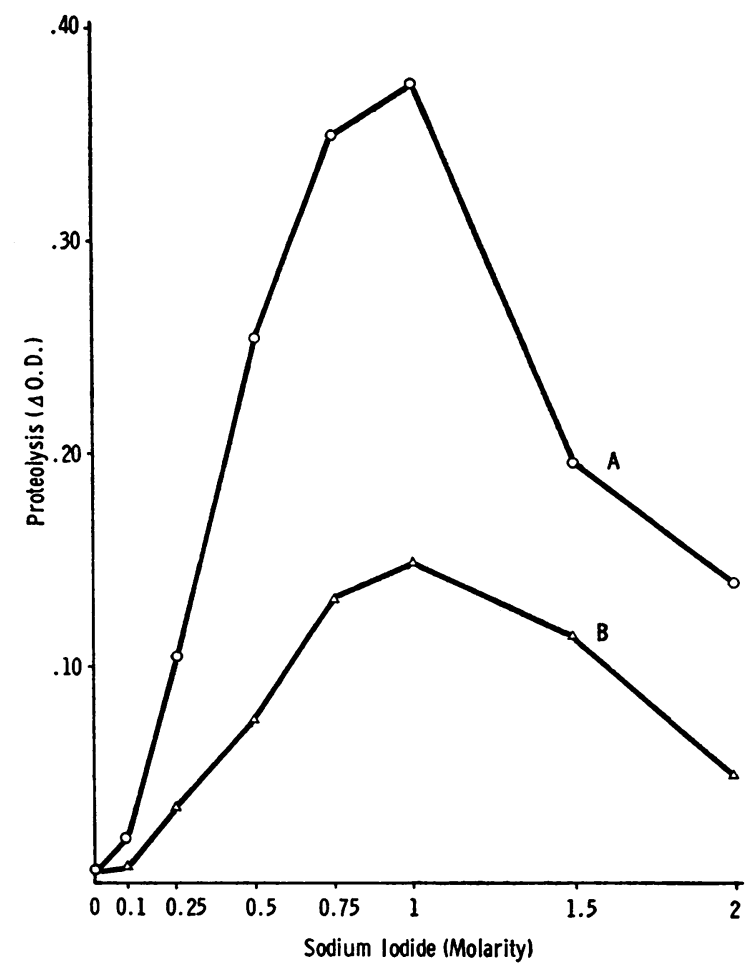

Fig. 6. Optimal NaI concentration fOR the inDUCTION OF PROTEOLYSIS IN (A) AN UNHEATED SPUTUM HOMOGENATE AND (B) A SPUTUM HOMOGENATE PREVIOUSLY HeATEd AT $65^{\circ} \mathrm{C}$ FOR 1 Hour. The unheated sputum preparation contains a "heat-labile" protease that is destroyed by heating at $65^{\circ} \mathrm{C}$ for 1 hour.

a 1-hour incubation period than in the $65^{\circ}$ C-heated preparation. Both systems demonstrated optimal enhancement of proteolysis at $1 \mathrm{M} \mathrm{NaI}$ concentration.

TABLE I

Effect of soybean-trypsin inhibitor (SBTI) upon the induction of proteolysis by $1 M$ sodium iodide in purulent sputum*

\begin{tabular}{|c|c|c|c|c|c|c|c|c|c|c|}
\hline \multirow[b]{3}{*}{ Sputum preparation } & \multirow{2}{*}{\multicolumn{3}{|c|}{$\begin{array}{l}\text { Spontaneous proteolysis } \\
\text { (OD) } \dagger\end{array}$}} & \multicolumn{6}{|c|}{ NaI-induced proteolysis (OD) $\dagger$} & \multirow{3}{*}{$\begin{array}{c}\% \\
\text { Inhi- } \\
\text { bition }\end{array}$} \\
\hline & & & & \multicolumn{3}{|c|}{ Without SBTI } & \multicolumn{3}{|c|}{ With SBTI } & \\
\hline & $0 \mathrm{hr}$ & $1 \mathrm{hr}$ & $\triangle \mathrm{OD}$ & $\mathrm{o} \mathrm{hr}$ & $1 \mathrm{hr}$ & $\triangle O D$ & $0 \mathrm{hr}$ & $1 \mathrm{hr}$ & $\triangle \mathrm{OD}$ & \\
\hline $\begin{array}{l}\text { Unheated sputum } \\
\text { homogenate }\end{array}$ & $\begin{array}{l}0.201 \\
0.205\end{array}$ & $\begin{array}{l}0.200 \\
0.203\end{array}$ & 0 & $\begin{array}{l}0.237 \\
0.240\end{array}$ & $\begin{array}{l}0.483 \\
0.487\end{array}$ & 0.248 & $\begin{array}{l}0.210 \\
0.205\end{array}$ & $\begin{array}{l}0.280 \\
0.271\end{array}$ & 0.068 & 70 \\
\hline $\begin{array}{l}65^{\circ} \mathrm{C} \text {-heated } \\
\text { sputum homog- } \\
\text { enate }\end{array}$ & $\begin{array}{l}0.191 \\
0.190\end{array}$ & $\begin{array}{l}0.183 \\
0.191\end{array}$ & 0 & $\begin{array}{l}0.220 \\
0.220\end{array}$ & $\begin{array}{l}0.291 \\
0.292\end{array}$ & 0.072 & $\begin{array}{l}0.205 \\
0.215\end{array}$ & $\begin{array}{l}0.274 \\
0.276\end{array}$ & 0.065 & 10 \\
\hline
\end{tabular}

* SBTI powder $(7.0 \mathrm{mg})$ was mixed with samples $(1.5 \mathrm{ml})$ of unheated and of $65^{\circ} \mathrm{C}$-heated sputum homogenates and allowed to stand at room temperature for 20 minutes. $\mathrm{NaI}(1.5 \mathrm{ml}$ of $2 \mathrm{M} \mathrm{NaI}$ in $0.05 \mathrm{M}$ sodium phosphate buffer, $\mathrm{pH}$ 7.5) was added to these samples and to samples of the same sputum homogenate lacking SBTI. The mixtures were incubated at $37^{\circ} \mathrm{C}$ and assayed for proteolysis with Folin-Ciocalteu (F-C) reagent as described under methods. Spontaneous proteolysis was measured in a mixture of $1.5 \mathrm{ml}$ sputum homogenate with $1.5 \mathrm{ml}, 0.05 \mathrm{M}, \mathrm{pH} 7.5$ sodium phosphate buffer.

†OD_=-optical density_of simultaneous_duplicate experiments. 


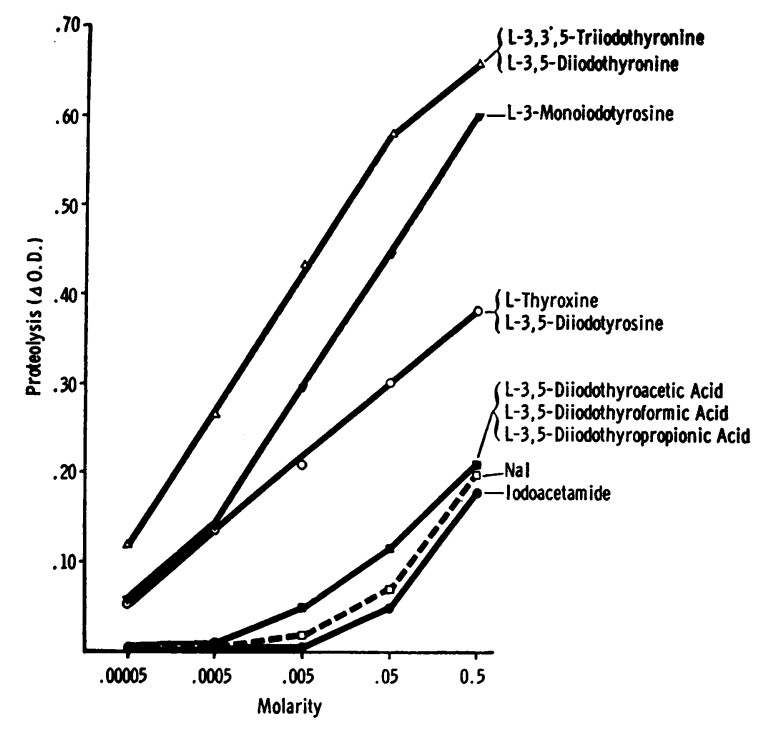

Fig. 7. INFLUENCE OF ORGANIC IODIDES ON PROTEOLYSIS IN PURULENT SPUTUM (1-HOUR INCUBATION) COMPARED to NaI.

Concentrations of $\mathrm{NaI}$ as low as $5 \mathrm{mM}$ appeared capable of inducing measurable proteolysis during a 1-hour incubation period. However, when the incubation period was extended to 24 to 48 hours, enhanced proteolysis could be detected with concentrations of $\mathrm{NaI}$ as low as $0.05 \mathrm{mM}$ (Table II). Spontaneous proteolysis was also measurable during this prolonged incubation but did not equal that occurring in the presence of $\mathrm{NaI}$.

\section{Effect of iodinated tyrosine and thyronine com- pounds}

Various iodinated tyrosine and thyronine compounds were tested for their ability to induce pro- teolysis in purulent sputum. Figure 7 shows the level of proteolysis induced by these compounds at different molar concentrations during a 1-hour incubation period. At $0.5 \mathrm{M}$ concentration, the most active compounds, di- and triiodothyronine and monoiodotyrosine (MIT), produced approximately 3 times as much proteolysis as sodium iodide. Tetraiodothyronine (thyroxine) and diiodotyrosine (DIT) were also more active than sodium iodide, but less active than monoiodotyrosine or di- and triiodothyronine. Analogues of diiodothyronine, in which the alanine chain is replaced by propionic, formic, or acetic acids, were much less effective than the thyronine compound and showed no greater proteolysis-inducing action than did sodium iodide. Iodoacetamide, an inhibitor of many enzymes, promoted proteolysis in sputum similar to sodium iodide.

Tyrosine itself had no proteolysis-inducing action, and substitution of bromide ion for iodide on the tyrosine did not allow proteolysis to pro. ceed (Figure 8).

Optimal concentration. The graphs in Figure 7 demonstrate that 0.005 to $0.0005 \mathrm{M}$ concentrations of the iodinated tyrosine and thyronine compounds induced proteolysis equal to that resulting from $0.5 \mathrm{M}$ sodium iodide. Further increases in concentration of these organic compounds promoted even higher rates of proteolysis (Figure 7), but this was shown to be dependent upon the concentration of sputum being used as substrate (Figure 9).

A series of dilutions of heat-inactivated $\left(80^{\circ} \mathrm{C}\right.$ for 1 hour) sputum homogenate was mixed with equal volumes of a series of DIT concentrations

TABLE II

Effect of low concentrations of NaI and prolonged incubation upon proteolysis of purulent sputum*

\begin{tabular}{|c|c|c|c|c|c|c|c|c|}
\hline \multirow{3}{*}{$\begin{array}{l}\text { Time of } \\
\text { incubation }\end{array}$} & \multicolumn{8}{|c|}{ Proteolysis } \\
\hline & \multicolumn{2}{|c|}{$5 \mathrm{mM} \mathrm{NaI}$} & \multicolumn{2}{|c|}{$0.5 \mathrm{mM} \mathrm{NaI}$} & \multicolumn{2}{|c|}{$0.05 \mathrm{mM} \mathrm{NaI}$} & \multicolumn{2}{|c|}{$\begin{array}{c}\text { Spontaneous proteolysis } \\
\text { control }\end{array}$} \\
\hline & OD & $\Delta \mathrm{OD}$ & OD & $\Delta \mathrm{OD}$ & OD & $\Delta \mathrm{OD}$ & OD & $\Delta \mathrm{OD}$ \\
\hline $0 \mathrm{hr}$ & $\begin{array}{l}0.168 \\
0.170\end{array} 0.169$ & & $\begin{array}{l}0.163 \\
0.165\end{array} 0.164$ & & $\begin{array}{l}0.160 \\
0.168\end{array}>0.164$ & & $\begin{array}{l}0.160 \\
0.165\end{array}>0.163$ & \\
\hline $24 \mathrm{hr}$ & $\begin{array}{l}0.365 \\
0.363\end{array}>0.364$ & 0.195 & 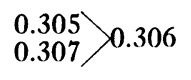 & 0.142 & $\begin{array}{l}0.221 \\
0.225\end{array}>0.223$ & 0.059 & $\begin{array}{l}0.200 \\
0.206\end{array}>0.203$ & 0.040 \\
\hline $48 \mathrm{hr}$ & $\begin{array}{l}0.470 \\
0.473\end{array}>0.472$ & 0.303 & $\begin{array}{l}0.413 \\
0.417\end{array}>0.415$ & 0.251 & $\begin{array}{l}0.310 \\
0.321\end{array}>0.316$ & 0.152 & $\begin{array}{l}0.251 \\
0.255\end{array} 0.253$ & 0.090 \\
\hline
\end{tabular}

* $5 \%$ sputum homogenate in $0.025 \mathrm{M}$ sodium phosphate buffer, $\mathrm{pH} 7.5$. 
in $0.05 \mathrm{M}$ sodium phosphate buffer, $\mathrm{pH}$ 7.5. Trypsin $(0.5 \mathrm{ml}$ of $2.0 \mathrm{mg}$ per $\mathrm{ml}$ in $0.001 \mathrm{~N}$ $\mathrm{HCl})$ was added to each mixture and to DIT blanks (no sputum) and incubated at $37^{\circ} \mathrm{C}$ for 1 hour. The rate of proteolysis was determined in the usual manner, and the control values for trypsin autolysis in DIT were subtracted. Figure 9 shows that maximal proteolysis was induced in the more dilute sputum homogenates by lower concentrations of DIT than were needed to induce maximal proteolysis in the more concentrated sputum homogenates. This direct relationship between DIT and sputum concentration is suggestive of a stoichiometric reaction. When the concentration of sputum homogenate was in excess relative to DIT [i.e., homogenate concentration (wt/vol): DIT (molarity) $>1$ ], the rate of the reaction was a function of DIT concentration. Similarly, when the concentration of DIT was in excess relative to the sputum concentration, the rate of the reaction was a function of the sputum concentration. Concentrations of sputum greater than $5 \%$ resulted in the same curve as that for $5 \%$ (Figure 9), indicating that substrate was present in excess.

Importance of the stereochemical structure of iodinated tyrosine and thyronine. Figure 10 shows the comparative rates of proteolysis caused by dextro- and levorotatory compounds in equimolar $(0.005 \mathrm{M})$ concentrations. The mixture of DL-

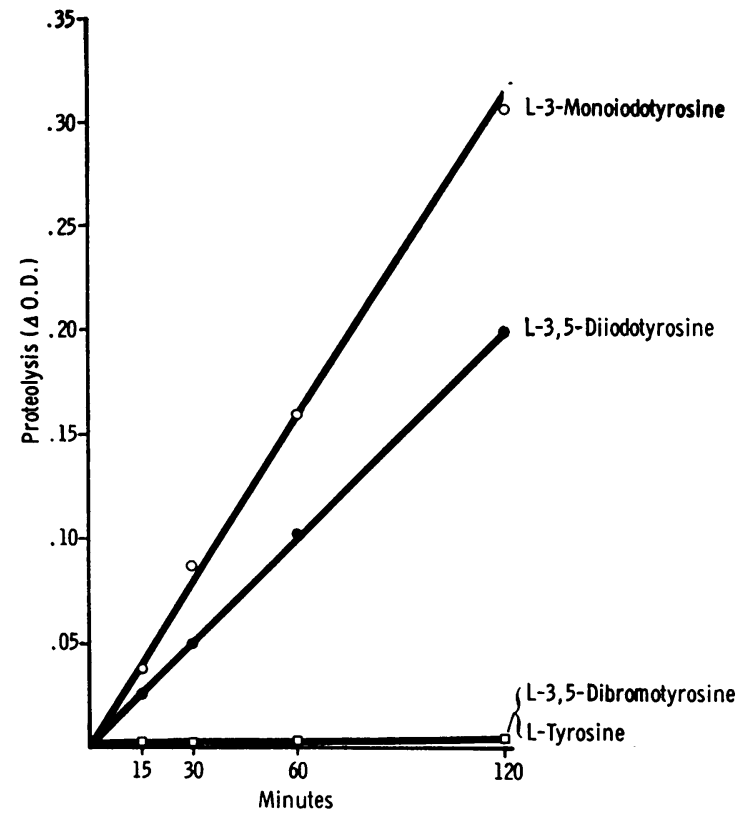

Fig. 8. EFFECT OF IODINATION OR BROMINATION UPON THE PROTEOLYSIS-INDUCING ACTION OF TYROSINE (5 MM) iN PURULENT SPUTUM.

diiodothyronine and the $\mathrm{D}$ isomers of thyroxine and diiodotyrosine are much less active than the pure L compounds. Thus, the stereochemical structure of the amino acid to which the iodide is attached appears to be important for causing maximal proteolysis within the purulent sputum.

This enhanced role for the $\mathrm{L}$ isomers was shown

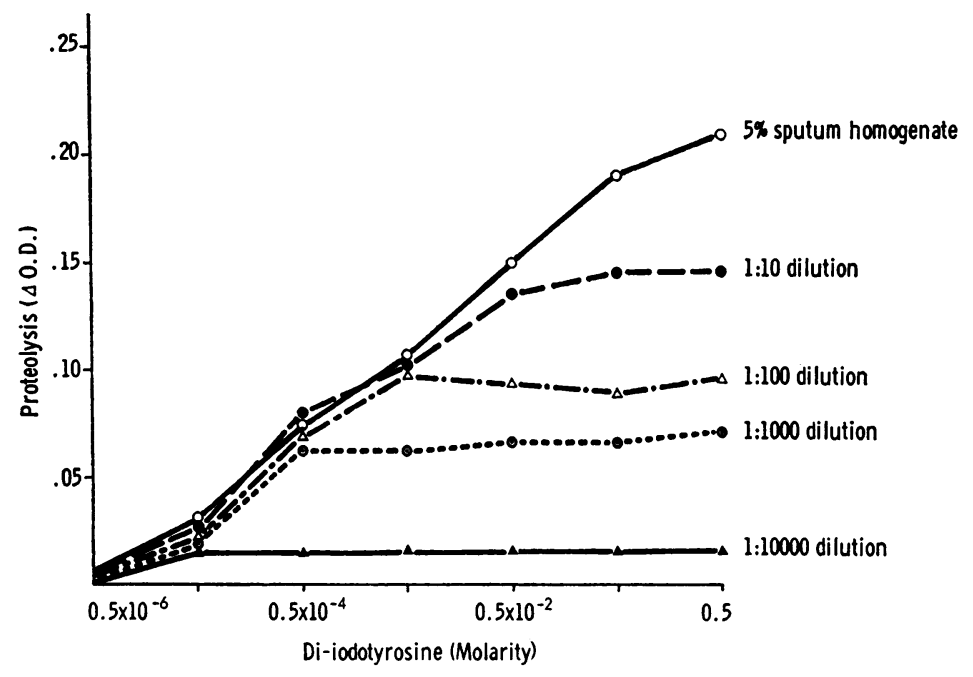

Fig. 9. EFFECt of Ditodotyrosine (DIT) CONCENTRATion on DigesTION OF VARIOUS Dilutions of $A \mathrm{~N} 80^{\circ} \mathrm{C}$-HEATED SPUTUM HOMOGENATE BY TRYPSIN. 


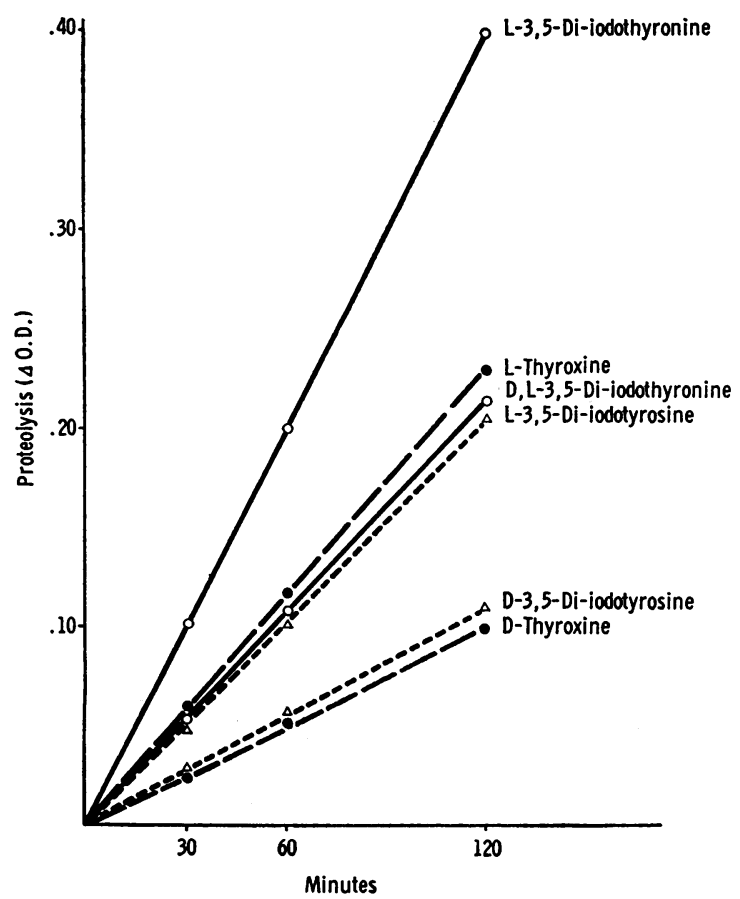

Fig. 10. COMParison OF DEXTRO- AND LEVOROTATORY ISOMERS FOR THE INDUCTION OF PROTEOLYTIC ACTIVITY IN PURULENT SPUTUM.

to depend upon the integrity of cells in the sputum preparation (Table III). When the cells contained in the sputum were disrupted by dis-

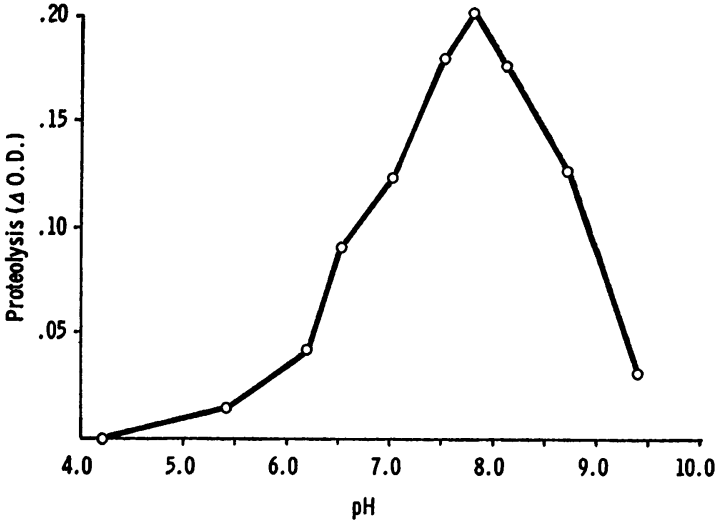

Fig. 11. Optimal PH CURve for PRoteolysis Induced BY 5 MM DIT IN A HOMOGENATE OF PURULENT SPUTUM.

solution in $2 \mathrm{M} \mathrm{NaCl}$, or by repeatedly washing the sediment with distilled water (which does not remove the enzyme from the sediment), or by the addition of Triton $\mathrm{X}-100$, the $\mathrm{D}$ and $\mathrm{L}$ isomers produced equal effects in promoting proteolysis in the sputum preparation (Table III).

Optimal pH for the induction of proteolysis with DIT. Samples of $5 \%$ sputum homogenate containing $0.005 \mathrm{M}$ DIT were assayed for pro. teolysis at various $\mathrm{pH}$ values during a 1 -hour in cubation period. Figure 11 demonstrates that maximal activity occurred at $\mathrm{pH} 7.5$ to 8.0 .

TABLE III

Comparison of proteolysis resulting from dextro- and levorotatory thyroxine in acellular and cell-containing sputum homogenates

\begin{tabular}{|c|c|c|c|c|c|c|c|}
\hline \multirow[b]{3}{*}{ Sputum preparation } & \multicolumn{6}{|c|}{ Proteolysis (OD) } & \multirow{3}{*}{$\begin{array}{l}\text { Ratio of } \\
\text { proteolytic } \\
\text { activity } \\
\text { in L- to } \\
\text { D-thyroxine }\end{array}$} \\
\hline & \multicolumn{3}{|c|}{ With L-thyroxine } & \multicolumn{3}{|c|}{ With D-thyroxine } & \\
\hline & $0 \mathrm{hr}$ & $2 \mathrm{hr}$ & $\begin{array}{c}\text { Activity } \\
(\Delta \mathrm{OD})\end{array}$ & $0 \mathrm{hr}$ & $2 \mathrm{hr}$ & $\begin{array}{c}\text { Activity } \\
(\Delta \mathrm{OD})\end{array}$ & \\
\hline \multicolumn{8}{|l|}{ A. Cell-containing homogenates* } \\
\hline $\begin{array}{l}\text { Homogenate in } \\
\text { physiological saline }\end{array}$ & $\begin{array}{l}0.405 \\
0.410\end{array}$ & $\begin{array}{l}0.685 \\
0.680\end{array}$ & 0.275 & $\begin{array}{l}0.400 \\
0.405\end{array}$ & $\begin{array}{l}0.530 \\
0.525\end{array}$ & 0.125 & 2.20 \\
\hline \multicolumn{8}{|l|}{ B. Acellular homogenates $\dagger$} \\
\hline $\begin{array}{l}\text { Sediment washed } 5 \text { to } 6 \\
\text { times with distilled water } \\
\text { (resuspended to original } \\
\text { volume) }\end{array}$ & $\begin{array}{l}0.428 \\
0.430\end{array}$ & $\begin{array}{l}0.745 \\
0.740\end{array}$ & 0.314 & $\begin{array}{l}0.417 \\
0.422\end{array}$ & $\begin{array}{l}0.720 \\
0.710\end{array}$ & 0.296 & 1.06 \\
\hline $\begin{array}{l}\text { Homogenate in distilled } \\
\text { water treated with } \\
\text { Triton X-100 }\end{array}$ & $\begin{array}{l}0.460 \\
0.455\end{array}$ & $\begin{array}{l}0.795 \\
0.797\end{array}$ & 0.339 & $\begin{array}{l}0.435 \\
0.445\end{array}$ & $\begin{array}{l}0.765 \\
0.763\end{array}$ & 0.324 & 1.05 \\
\hline Homogenate in $2 \mathrm{M} \mathrm{NaCl}$ & $\begin{array}{l}0.419 \\
0.422\end{array}$ & $\begin{array}{l}0.829 \\
0.825\end{array}$ & 0.407 & $\begin{array}{l}0.421 \\
0.428\end{array}$ & $\begin{array}{l}0.794 \\
0.788\end{array}$ & 0.367 & 1.11 \\
\hline
\end{tabular}

* Microscopic examination reveals intact cells.

$\dagger$ Microscopic examination reveals no cells, only amorphous material. 
TABLE IV

Effect of $5 m M$ diiodotyrosine (DIT) upon proteolysis of various substrates at $p H 7.5$ by sputum protease, trypsin, and chymotrypsin*

\begin{tabular}{|c|c|c|c|c|c|c|c|c|c|c|c|c|c|c|c|}
\hline \multirow[b]{5}{*}{ Enzyme } & \multicolumn{15}{|c|}{ Substrate } \\
\hline & \multirow{2}{*}{\multicolumn{3}{|c|}{$\begin{array}{c}\text { Caseint } \\
1 \%\end{array}$}} & \multirow{2}{*}{\multicolumn{3}{|c|}{$\begin{array}{l}\text { Denatured hemoglobin } \ddagger \\
\qquad 1 \%\end{array}$}} & \multicolumn{3}{|c|}{ Gelatin§ } & \multicolumn{3}{|c|}{ Albumin $\|$} & \multicolumn{3}{|c|}{ Sputum protein } \\
\hline & & & & & & & & $1 \%$ & & \multicolumn{3}{|c|}{$1 \%$} & \multicolumn{3}{|c|}{$5 \%$} \\
\hline & \multicolumn{15}{|c|}{ Proteolysis $(\Delta \mathrm{OD})^{* *}$} \\
\hline & $\begin{array}{l}\text { No } \\
\text { DIT }\end{array}$ & $\begin{array}{l}\text { With } \\
\text { DIT }\end{array}$ & $\begin{array}{c}\% \\
\text { Change }\end{array}$ & No & $\begin{array}{l}\text { With } \\
\text { DIT }\end{array}$ & $\begin{array}{c}\% \\
\text { Change }\end{array}$ & No & $\begin{array}{l}\text { With } \\
\text { DIT }\end{array}$ & $\begin{array}{c}\% \\
\text { Change }\end{array}$ & $\begin{array}{l}\text { No } \\
\text { DIT }\end{array}$ & $\begin{array}{l}\text { With } \\
\text { DIT }\end{array}$ & $\begin{array}{c}\% \\
\text { Change }\end{array}$ & No & $\begin{array}{l}\text { With } \\
\text { DIT }\end{array}$ & $\begin{array}{c}\% \\
\text { Change }\end{array}$ \\
\hline & & & $\%$ & & & $\%$ & & & $\%$ & & & $\%$ & & & $\%$ \\
\hline $\begin{array}{l}\text { protease, } \\
10 \% \text { wt/vol } \\
\text { extract in } \\
1 \mathrm{M} \mathrm{NaCl}\end{array}$ & 0.265 & 0.237 & -10.5 & 0.312 & 0.293 & -6.5 & 0.210 & 0.183 & -4.3 & 0.040 & 0.015 & & 0.001 & 0.106 & + \\
\hline $\begin{array}{l}\text { Trypsin, } \\
\quad 0.2 \mathrm{mg} / \mathrm{ml}\end{array}$ & 0.649 & 0.640 & -1.4 & 0.316 & 0.387 & +22.4 & 0.263 & 0.272 & +3.4 & 0.466 & 0.488 & +4.7 & 0.000 & 0.175 & + \\
\hline $\begin{array}{l}\text { Chymotrypsin, } \\
5,000 \text { Armour } \\
\text { Uं/mltt }\end{array}$ & 0.404 & 0.497 & +23.0 & 0.504 & 0.522 & +3.6 & 0.281 & 0.205 & -6.0 & 0.196 & 0.172 & $2-12.5$ & 0.000 & 0.101 & + \\
\hline
\end{tabular}

* $2.5 \mathrm{ml}$ of each substrate in $0.05 \mathrm{M}$ phosphate buffer, $\mathrm{pH} 7.5(2 \% \mathrm{wt} / \mathrm{vol}$ solutions, except sputum protein, $10 \%$ solution) was mixed with an equal volume of either the phosphate buffer or $0.01 \mathrm{M}$ DIT in the buffer. $0.5 \mathrm{ml}$ of each enzyme (type and concentration listed in the table) was added to each substrate mixture, and the tubes were incubated at $37^{\circ} \mathrm{C}$ for 1 hour. Samples $(2.0 \mathrm{ml})$ were mixed with $4.0 \mathrm{ml}$ of $16 \%$ trichloroacetic acid (TCA) at 0 hour and 1 hour. Proteolysis was assayed with the F-C reagent as described under Methods.

t Vitamin-free casein, Pfanstiehl Laboratories, Inc., Waukegan, III.

Hemoglobin (denatured), Nutritional Biochemicals Corp., Cleveland, Ohio.

Knox unflavored gelatin, Knox Gelatine, Inc., Johnstown, N. Y.

Albumin, human (crystallized), Mann Research Laboratories, Inc., New York, N. Y.

I Sputum heated at $80^{\circ} \mathrm{C} \times 1$ hour at $\mathrm{pH} 8.0$ to destroy intrinsic protease activity.

** OD values $=$ change in optical density, average of duplicate assays.

t† One-tenth the concentration of chymotrypsin was used with casein substrate.

Substrate specificity for enhanced proteolysis with DIT

DIT was tested for its effect upon the activities of sputum protease, trypsin, and chymotrypsin with substrates other than the sputum itself. Casein, denatured hemoglobin, gelatin, and human crystalline albumin ( $1 \%$ concentrations) were used as substrates (Table IV). The data show that $0.005 \mathrm{M}$ DIT has no activating or inhibitory effect upon these proteases with these other substrates, but that DIT does allow proteolysis of sputum protein. We have also observed that the autolysis of trypsin and chymotrypsin is enhanced by the presence of DIT, necessitating the inclusion of blanks containing only the enzyme and DIT. Appropriate blanks were also needed when the sputum protease was studied with other substrates, since the $0.5 \mathrm{ml}$ of sputum homogenate used as enzyme was also readily hydrolyzed in the presence of DIT.

\section{Effect of DIT upon boiled sputum substrate}

A $10 \%$ sputum homogenate in distilled water was placed in a boiling water bath for 30 minutes and was then tested for $a$ ) the presence of a trypsin inhibitor and $b$ ) the influence of DIT on tryptic digestion of the boiled sputum. The purpose of this experiment was to determine whether or not the enhancement of proteolysis in sputum by DIT could be due to the inactivation of a protease inhibitor by DIT.

One-half $\mathrm{ml}$ samples of trypsin $(0.2 \mathrm{mg}$ per $\mathrm{ml})$ were mixed with $0.5-\mathrm{ml}$ samples of the boiled sputum homogenate and incubated at room temperature for 30 minutes before the addition of 5.0 $\mathrm{ml}$ of $1 \%$ casein (in $0.05 \mathrm{M}$ sodium phosphate buffer, $\mathrm{pH}$ 7.5). The mixture was incubated at

TABLE V

A test of trypsin-inhibitory activity by $a$ boiled sputum homogenate*

\begin{tabular}{|c|c|c|c|c|}
\hline \multirow{3}{*}{$\begin{array}{l}\text { Time of } \\
\text { incubation }\end{array}$} & \multicolumn{4}{|c|}{ Hydrolysis of casein by trypsin } \\
\hline & \multicolumn{2}{|c|}{$\begin{array}{l}\text { In presence of } \\
\text { boiled-sputum } \\
\text { homogenate }\end{array}$} & \multicolumn{2}{|c|}{$\begin{array}{l}\text { In presence of } \\
\text { distilled water }\end{array}$} \\
\hline & OD & $\triangle \mathrm{OD}$ & OD & $\triangle \mathrm{OD}$ \\
\hline $0 \mathrm{hr}$ & $\begin{array}{l}0.175 \\
0.175\end{array}>0.175$ & & $\begin{array}{l}0.110 \\
0.105\end{array}>0.107$ & \\
\hline $15 \mathrm{~min}$ & $\begin{array}{l}0.390 \\
0.400\end{array}>0.395$ & 0.220 & $\begin{array}{l}0.320 \\
0.315\end{array}>0.318$ & 0.211 \\
\hline $30 \mathrm{~min}$ & $\begin{array}{l}0.585 \\
0.580\end{array}>0.583$ & 0.409 & $\begin{array}{l}0.535 \\
0.540\end{array}>0.537$ & 0.430 \\
\hline
\end{tabular}

* See text for procedure. 
TABLE VI

Effect of $5 \mathrm{mM}$ diiodotyrosine (DIT) upon the proteolysis of boiled sputum homogenate by trypsin*

\begin{tabular}{|c|c|c|c|c|c|c|c|c|c|}
\hline \multirow{3}{*}{$\begin{array}{l}\text { Time of } \\
\text { incubation }\end{array}$} & \multicolumn{4}{|c|}{ Proteolysis of boiled sputum } & \multicolumn{4}{|c|}{ Trypsin autolysis } & \multirow{3}{*}{$\begin{array}{c}\text { Net pro- } \\
\text { teolysis } \\
\text { of boiled } \\
\text { sputum } \\
\text { with DIT } \\
\text { (B minus D }\end{array}$} \\
\hline & \multicolumn{2}{|c|}{$\begin{array}{c}\text { A } \\
\text { Without DIT }\end{array}$} & \multicolumn{2}{|c|}{$\begin{array}{c}\text { B } \\
\text { With DIT }\end{array}$} & \multicolumn{2}{|c|}{$\begin{array}{c}\mathrm{C} \\
\text { Without DIT }\end{array}$} & \multicolumn{2}{|c|}{$\begin{array}{c}\mathrm{D} \\
\text { With DIT }\end{array}$} & \\
\hline & OD & $\overline{\Delta \mathrm{OD}}$ & OD & $\overline{\Delta \mathrm{OD}}$ & OD & $\overline{\Delta \mathrm{OD}}$ & $\overline{O D}$ & $\overline{\Delta O D}$ & \\
\hline $0 \mathrm{hr}$ & $\begin{array}{l}0.257 \\
0.260\end{array}$ & & $\begin{array}{l}0.597 \\
0.603\end{array}$ & & $\begin{array}{l}0.059 \\
0.057\end{array}$ & & $\begin{array}{l}0.767 \\
0.753\end{array}$ & & \\
\hline $30 \mathrm{~min}$ & $\begin{array}{l}0.265 \\
0.269\end{array}$ & 0.008 & $\begin{array}{l}0.775 \\
0.786\end{array}$ & 0.181 & $\begin{array}{l}0.063 \\
0.068\end{array}$ & 0.008 & $\begin{array}{l}0.829 \\
0.837\end{array}$ & 0.073 & 0.108 \\
\hline $60 \mathrm{~min}$ & $\begin{array}{l}0.281 \\
0.277\end{array}$ & 0.020 & $\begin{array}{l}0.995 \\
1.000\end{array}$ & 0.398 & $\begin{array}{l}0.075 \\
0.078\end{array}$ & 0.019 & $\begin{array}{l}0.910 \\
0.925\end{array}$ & 0.158 & 0.240 \\
\hline
\end{tabular}

* $2.5 \mathrm{ml}$ boiled $10 \%$ sputum homogenate or $\mathrm{H}_{2} \mathrm{O}$ for control $+2.5 \mathrm{ml} 0.01 \mathrm{M}$ DIT in $0.05 \mathrm{M}, \mathrm{pH} 7.5$ sodium phosphate buffer or buffer alone +0.5 trypsin $(2.2 \mathrm{mg}$ per $\mathrm{ml})$.

TABLE VII

Assay of iodide-induced proteolysis by various techniques*

\begin{tabular}{|c|c|c|c|c|c|c|c|c|}
\hline & \multicolumn{8}{|c|}{ Method of assay } \\
\hline & \multicolumn{4}{|c|}{ Folin-Ciocalteu reagent } & \multirow{2}{*}{\multicolumn{2}{|c|}{$\frac{\text { Absorbance at } 280 \mathrm{~m} \mu}{\text { TCA-supernate }}$}} & \multirow{2}{*}{\multicolumn{2}{|c|}{$\begin{array}{c}\text { Ninhydrin reagent } \\
\text { TCA-supernate } \\
\end{array}$}} \\
\hline & \multicolumn{2}{|c|}{ TCA-supernate } & \multicolumn{2}{|c|}{ TCA-sediment } & & & & \\
\hline & OD & $\triangle \mathrm{OD}$ & OD & $\Delta \mathrm{OD}$ & OD & $\Delta \mathrm{OD}$ & OD & $\Delta \mathrm{OD}$ \\
\hline \multicolumn{9}{|c|}{ A. Spontaneous proteolysis } \\
\hline $0 \mathrm{hr}$ & $\begin{array}{l}0.155 \\
0.153\end{array}$ & & $\begin{array}{l}0.550 \\
0.551\end{array}$ & & $\begin{array}{l}0.252 \\
0.250\end{array}$ & & $\begin{array}{l}0.500 \\
0.505\end{array}$ & \\
\hline $30 \mathrm{~min}$ & $\begin{array}{l}0.150 \\
0.155\end{array}$ & $\mathbf{0}$ & $\begin{array}{l}0.550 \\
0.555\end{array}$ & $\mathbf{0}$ & $\begin{array}{l}0.243 \\
0.251\end{array}$ & 0 & $\begin{array}{l}0.490 \\
0.500\end{array}$ & 0 \\
\hline $60 \mathrm{~min}$ & $\begin{array}{l}0.157 \\
0.158\end{array}$ & +0.004 & $\begin{array}{l}0.547 \\
0.565\end{array}$ & -0.005 & $\begin{array}{l}0.247 \\
0.249\end{array}$ & $\mathbf{0}$ & $\begin{array}{l}0.485 \\
0.485\end{array}$ & 0 \\
\hline $120 \mathrm{~min}$ & $\begin{array}{l}0.160 \\
0.160\end{array}$ & +0.006 & $\begin{array}{l}0.543 \\
0.540\end{array}$ & -0.008 & $\begin{array}{l}0.250 \\
0.253\end{array}$ & +0.001 & $\begin{array}{l}0.510 \\
0.500\end{array}$ & +0.002 \\
\hline \multicolumn{9}{|c|}{ B. NaI $\underset{\text { proteolysis }}{(1 \mathrm{M}) \text {-induced }}$} \\
\hline $\mathrm{O} \mathrm{hr}$ & ${ }_{0.205}^{0.210 \dagger}$ & & $\begin{array}{l}0.470 \\
0.475\end{array}$ & & $\begin{array}{l}1.431 \ddagger \\
1.426\end{array}$ & & $\begin{array}{l}0.515 \\
0.515\end{array}$ & \\
\hline $30 \mathrm{~min}$ & $\begin{array}{l}0.250 \\
0.253\end{array}$ & +0.044 & $\begin{array}{l}0.421 \\
0.424\end{array}$ & -0.050 & $\begin{array}{l}1.468 \\
1.471\end{array}$ & +0.041 & $\begin{array}{l}0.530 \\
0.530\end{array}$ & +0.015 \\
\hline $60 \mathrm{~min}$ & $\begin{array}{l}0.327 \\
0.321\end{array}$ & +0.116 & $\begin{array}{l}0.385 \\
0.387\end{array}$ & -0.087 & $\begin{array}{l}1.517 \\
1.509\end{array}$ & +0.084 & $\begin{array}{l}0.575 \\
0.580\end{array}$ & +0.063 \\
\hline $120 \mathrm{~min}$ & $\begin{array}{l}0.430 \\
0.429\end{array}$ & +0.222 & $\begin{array}{l}0.295 \\
0.291\end{array}$ & -0.180 & $\begin{array}{l}1.596 \\
1.590\end{array}$ & +0.164 & $\begin{array}{l}0.640 \\
0.675\end{array}$ & +0.143 \\
\hline \multicolumn{9}{|c|}{$\begin{array}{c}\text { C. DIT } \\
\text { proteolysis } \\
(0.005 \mathrm{M}) \text {-induced }\end{array}$} \\
\hline $0 \mathrm{hr}$ & $\begin{array}{l}0.5738 \\
0.610\end{array}$ & & $\begin{array}{l}0.361 \\
0.365\end{array}$ & & $\begin{array}{l}1.4618 \\
1.498\end{array}$ & & $\begin{array}{l}0.520 \\
0.560\end{array}$ & \\
\hline $30 \mathrm{~min}$ & $\begin{array}{l}0.679 \\
0.675\end{array}$ & +0.085 & $\begin{array}{l}0.305 \\
0.300\end{array}$ & -0.060 & $\begin{array}{l}1.620 \\
1.598\end{array}$ & +0.120 & $\begin{array}{l}0.580 \\
0.580\end{array}$ & +0.040 \\
\hline $60 \mathrm{~min}$ & $\begin{array}{l}0.725 \\
0.718\end{array}$ & +0.129 & $\begin{array}{l}0.240 \\
0.243\end{array}$ & -0.121 & $\begin{array}{l}1.732 \\
1.728\end{array}$ & +0.250 & $\begin{array}{l}0.610 \\
0.620\end{array}$ & +0.075 \\
\hline $120 \mathrm{~min}$ & $\begin{array}{l}0.820 \\
0.861\end{array}$ & +0.249 & $\begin{array}{l}0.157 \\
0.150\end{array}$ & -0.210 & $\begin{array}{l}2.004 \\
1.961\end{array}$ & +0.053 & $\begin{array}{l}0.680 \\
0.700\end{array}$ & +0.150 \\
\hline
\end{tabular}

* Samples of a $10 \%$ purulent sputum homogenate were mixed with equal volumes of $0.05 \mathrm{M}, \mathrm{pH} 7.5$ sodium phosphate buffer, or $2 \mathrm{M}$ NaI in the same buffer, or $0.01 \mathrm{M}$ DIT in the buffer, and incubated at $37^{\circ} \mathrm{C}$. The mixtures were sampled at intervals and mixed with 2 parts $16 \%$ TCA.

The TCA-supernatant fluids and sediments were then subjected to the various assays as described under methods. to the immediate nonenzymatic release of a small amount of acid-soluble material by the NaI.

$\ddagger$ Sodium iodide and TCA react to form a compound that absorbs at $280 \mathrm{~m} \mu$ and is associated with a yellow discoloration of the solution. A blank containing only TCA and NaI gives an absorbance of slightly greater than $1.0 \mathrm{OD}$, but the absorbance increases with time. For this reason the measurement of absorbance at $280 \mathrm{~m} \mu$ is a poor method for measuring proteolysis in the presence of NaI. The reaction of NaI with TCA did not affect the Folin-Ciocalteu (F-C) color development, however.

The initial high OD is due to the added DIT and to the immediate nonenzymatic release of a small amount of acid-soluble material by the DIT. This effect is apparently more marked on the absorbance at $280 \mathrm{~m} \mu$ than on the intensity of the F-C reaction, because of the greater slope of the absorbance: concentration curve at $280 \mathrm{~m} \mu$. 
$37^{\circ} \mathrm{C}$ and sampled at 15 - and 30-minute intervals. Comparison to a similar preparation utilizing distilled water instead of boiled sputum homogenate revealed that the sputum did not inhibit trypsin activity (Table V).

When the boiled sputum homogenate was used as substrate for trypsin $(0.2 \mathrm{mg}$ per $\mathrm{ml}$ final concentration), it resisted proteolysis completely in the absence of DIT but was hydrolyzed by trypsin in the presence of $0.005 \mathrm{M}$ DIT (Table VI).

Since trypsin-inhibitory activity could not be demonstrated in the boiled sputum preparation, and since DIT can induce tryptic proteolysis of the boiled sputum, this action of DIT probably is not dependent upon the removal of a protease inhibitor.

\section{Other methods of assay}

Data obtained from four different methods for assaying proteolysis are shown in Table VII. All four methods showed minimal spontaneous proteolysis in a $10 \%$ homogenate of purulent sputum during a 2-hour incubation, but all the assay

TABLE VIII

A survey of DIT-induced proteolysis in purulent sputum and pus

\begin{tabular}{|c|c|c|c|c|c|}
\hline Age & Sex & Diagnosis & $\begin{array}{l}\text { Units } \\
\text { ATEEase } \\
\text { activity* }\end{array}$ & $\begin{array}{c}\text { 1-hr } \\
\text { spontaneous } \\
\text { proteolysis }\end{array}$ & $\begin{array}{c}1 \text {-hr } \\
\text { DIT-induced } \\
\text { proteolysis }\end{array}$ \\
\hline 37 & $\mathrm{M}$ & Asthma & 0.25 & 0.003 & 0.036 \\
\hline 46 & M & Pneumonia & 0.5 & 0.002 & 0.041 \\
\hline 69 & M & Asthma & 0.5 & 0.006 & 0.061 \\
\hline 65 & $\mathrm{M}$ & Emphysema & 1.0 & 0.004 & 0.132 \\
\hline 47 & $\mathrm{M}$ & Chronic bronchitis & 1.1 & 0.002 & 0.118 \\
\hline 43 & $\mathrm{M}$ & Chronic bronchitis & 1.25 & 0.005 & 0.079 \\
\hline 35 & $\mathrm{~F}$ & Bronchitis & 1.6 & 0.008 & 0.050 \\
\hline 71 & $\mathrm{M}$ & Tuberculosis & 2.0 & 0.003 & 0.156 \\
\hline 46 & $\mathbf{M}$ & Bronchogenic carcinoma & 2.1 & 0.002 & 0.195 \\
\hline 43 & M & Bronchitis & 2.6 & 0.000 & 0.221 \\
\hline 43 & M & Bronchiectasis & 4.0 & 0.002 & 0.210 \\
\hline 57 & $\mathbf{M}$ & Lung abscess & 5.6 & 0.006 & 0.115 \\
\hline 74 & M & Inactive tuberculosis & 5.9 & 0.002 & 0.118 \\
\hline 39 & M & Bronchiectasis & 6.0 & 0.004 & 0.257 \\
\hline 46 & M & Inactive tuberculosis & 7.5 & 0.000 & 0.140 \\
\hline 40 & M & Asthma & 9.8 & 0.000 & 0.138 \\
\hline 4 & M & Cystic fibrosis & 12.5 & 0.000 & 0.132 \\
\hline 35 & $\mathrm{M}$ & Asthma & 15.0 & 0.000 & 0.244 \\
\hline 8 & $\mathrm{M}$ & Cystic fibrosis & 17.5 & 0.000 & 0.257 \\
\hline 68 & $\mathrm{M}$ & Emphysema & 18.0 & 0.004 & 0.202 \\
\hline 13 & $\mathrm{~F}$ & Cystic fibrosis & 20.0 & 0.000 & 0.274 \\
\hline 27 & $\mathrm{M}$ & Pneumonia & 20.6 & 0.002 & 0.258 \\
\hline 76 & . $\mathrm{M}$ & Bronchogenic carcinoma & 22.5 & 0.003 & 0.206 \\
\hline 76 & M & Asthma & 22.5 & 0.006 & 0.078 \\
\hline 13 & $\mathbf{M}$ & Cystic fibrosis & 23.0 & 0.006 & 0.172 \\
\hline 6 & $\mathrm{M}$ & Cystic fibrosis & 26.3 & 0.003 & 0.245 \\
\hline 11 & $\mathrm{M}$ & Cystic fibrosis & 26.3 & 0.000 & 0.276 \\
\hline 7 & $\mathrm{M}$ & Cystic fibrosis & 28.1 & 0.001 & 0.294 \\
\hline 73 & $\mathrm{M}$ & Emphysema & 29.0 & 0.000 & 0.079 \\
\hline 54 & $\mathrm{~F}$ & Bronchiectasis & 32.0 & 0.001 & 0.222 \\
\hline 14 & M & Cystic fibrosis & 40.0 & 0.000 & 0.257 \\
\hline 73 & $\mathrm{M}$ & Bronchiectasis & 42.5 & 0.002 & 0.235 \\
\hline \multirow[t]{2}{*}{10} & M & Cystic fibrosis & 48.0 & 0.004 & 0.179 \\
\hline & $\mathrm{F}$ & Pus from right kidney abscess $\dagger$ & 50.0 & 0.001 & 0.070 \\
\hline \multirow[t]{2}{*}{16} & $\mathrm{~F}$ & Cystic fibrosis & 51.3 & 0.006 & 0.228 \\
\hline & $\mathrm{F}$ & Pus (empyema) $\dagger$ & 56.0 & 0.005 & 0.104 \\
\hline 16 & M & Bronchitis & 50.0 & 0.000 & 0.142 \\
\hline 12 & $\mathrm{M}$ & Cystic fibrosis & 71.0 & 0.003 & 0.255 \\
\hline 9 & $\mathrm{~F}$ & Cystic fibrosis & 75.0 & 0.000 & 0.289 \\
\hline 7 & $\mathrm{~F}$ & Cystic fibrosis & 79.0 & 0.000 & 0.249 \\
\hline 13 & M & Cystic fibrosis & 80.6 & 0.000 & 0.244 \\
\hline 9 & $\mathrm{~F}$ & Cystic fibrosis & 82.0 & 0.000 & 0.258 \\
\hline 10 & $\mathrm{~F}$ & Cystic fibrosis & 85.0 & 0.000 & 0.285 \\
\hline 15 & $\mathrm{~F}$ & Cystic fibrosis & 100.0 & 0.004 & 0.294 \\
\hline
\end{tabular}

* ATEE $=N$-acetyl-L-tyrosine ethyl ester.

† Prepared as $10 \%$ homogenates in distilled water. 
techniques demonstrated that active proteolysis took place in the presence of $1 \mathrm{M} \mathrm{NaI}$ or $0.005 \mathrm{M}$ DIT.

\section{Reproducibility of the DIT effect on proteolysis} in purulent sputa

Forty-two specimens of purulent sputum and two samples of pus were prepared as $10 \%$ homogenates in distilled water. Each specimen was assayed with $0.01 \mathrm{M} N$-acetyl-L-tyrosine ethyl ester (ATEE) substrate as an estimate of protease content (4). Samples $(2.5 \mathrm{ml})$ of each homogenate were then mixed with equal volumes of $0.05 \mathrm{M}$ sodium phosphate buffer, $\mathrm{pH} 7.5$, to measure spontaneous proteolysis, or with $0.01 \mathrm{M}$ DIT in the buffer at $\mathrm{pH} 7.5$, and incubated at $37^{\circ} \mathrm{C}$. At intervals of $0,30,60$, and 120 minutes, $1.0-\mathrm{ml}$ samples were removed and mixed with 2.0 $\mathrm{ml} 16 \%$ TCA. The TCA-supernatant fluid was then tested for the degree of proteolysis with the F-C reagent.

DIT-induced proteolysis was linear with time. Table VIII contains the data for spontaneous proteolysis as compared with DIT-induced proteolysis for the 1-hour incubation period. The specimens are listed in the order of increasing activity with ATEE substrate. None of the specimens showed any appreciable spontaneous proteolysis during the 1-hour incubation, but all of them showed enhanced proteolysis in the presence of $0.005 \mathrm{M}$ DIT. The DIT-induced proteolysis was roughly proportional in rate to the hydrolysis of ATEE by the sputum specimens, up to an ATEE hydrolytic activity corresponding to $25 \mathrm{U}$. Sputa that contained higher levels of ATEE hydrolytic activity did not demonstrate further increases in DIT-induced proteolysis because of the limiting concentration of DIT (Figure 9).

\section{Discussion}

In the past it has been thought that iodides act to thin purulent respiratory secretions simply by increasing the volume of aqueous secretion from the bronchial glands. However, our experiments suggest that iodides may have a more specific role and that they liquefy purulent secretions by inducing the enzymatic hydrolysis of protein. This action of iodides requires the presence of a proteolytic enzyme: either inherent leukocytic pro- teases or an added protease such as trypsin. Since the reaction is enzymatic, inhibition of the enzyme prevents proteolysis.

Although the data demonstrate optimal proteol$y$ sis at a concentration of $1 \mathrm{M}$ sodium iodide, considerable proteolysis was apparent at $0.005 \mathrm{M}$ (Table II and Figure 7). Even lower concentrations may be clinically effective, since the amount of proteolysis that must take place to reduce the viscosity of sputum is very slight compared to the levels of proteolysis attained under optimal in vitro conditions. For example, we have demonstrated effective liquefaction of whole purulent sputum by the addition of trypsin (7), although the level of measurable proteolysis resulting from tryptic activity is minimal.

The mechanism whereby iodides induce proteolysis does not appear to depend upon the dissociation of nucleoprotein complexes and thus differs from the manner in which deoxyribonuclease and high $\mathrm{NaCl}$ concentrations act. The reaction is substrate specific in that proteolysis of some protein substrates other than sputum, such as casein, albumin, hemoglobin, and gelatin, was not affected by the iodides. In addition, this effect of iodides is not enzyme specific, since the action of trypsin and chymotrypsin upon a heated sputum preparation (lacking inherent protease activity) was also enhanced by the iodides. The iodides appear to act by altering the potential protein substrate in sputum so that it is more readily hydrolyzed by proteolytic enzymes. The nature of this protein substrate and the changes caused by the iodides is under study. The splitting of glycoproteins, analogous to the splitting of nucleoproteins by DNase, is suggested to be the mechanism whereby iodides induce proteolysis.

The naturally occurring iodinated thyroidal compounds were much more effective for initiating proteolysis in a homogenate of purulent sputum than were the inorganic iodides. Lower concentrations of these natural compounds were required, and faster rates of proteolysis resulted. It is possible that the reaction is specific for iodinated tyrosine or thyronine and that inorganic iodide must first form iodinated amino acids to have an effect. In the absence of iodination, on the other hand, the parent amino acid (tyrosine) lacked this activity, as did brominated tyrosine. The action of the organic iodine compounds appeared 
to result from a stoichiometric reaction between the compound and sputum protein, with either the organic iodine compound or the sputum protein being the limiting factor in determining the rate of proteolysis when the other was present in excess.

Use of both dextro- and levoisomers of the iodinated thyronine and tyrosine compounds suggests that some of the substrate affected by the iodides is intracellular. The levorotatory compounds were consistently more effective than the dextrorotatory compounds, but these differences were eliminated by disrupting the cells contained in the sputum preparation.

These observations raise the question of whether thyroxine and its precursors directly affect proteolysis in vivo in cellular metabolism. Evidence that thyroid hormone influences enzymatic activity has long been sought, but very few such reactions have been found to be affected by thyroxine in vitro $(8,9)$. Barker has shown such an effect in carbohydrate oxidation (10), but the effect lacked specificity since it could be produced by metabolically inactive analogues of thyroxine. The test system employed by Barker, however, was essentially a cell-free system, and possibly in vivo specificity of thyroid hormone depends upon its ability to cross the cell membrane. In our experiments no difference between the $\mathrm{D}$ and L compounds was observed when a cell-free system was used, but a definite advantage of the metabolically active $\mathrm{L}$ compounds over the $\mathrm{D}$ isomers was apparent when cells were contained in the system. However, the reaction is not completely specific for metabolically active compounds, since iodinated tyrosines (MIT and DIT), thought to be metabolically inactive, similarly enhance proteolysis in sputum. Other metabolically inactive analogues of thyroxine (diiodothyropropionic, -acetic, and -formic acids) are much less active than iodinated thyronine and tyrosine, suggesting some selective advantage for the thyroidal hormones. The order of effectiveness of the organic iodides for inducing proteolysis (diiodothyronine $=$ triiodothyronine $>$ monoiodotyrosine $>$ thyroxine $=$ diiodotyrosine $)$ is not correlated with the metabolic activity in vivo. The difference between the metabolic effect in vivo and the proteolyticenhancing effect in vitro may depend upon dif- ferences in penetration of viable cells by the iodinated compounds.

The lowest concentration of DIT or L-thyroxine that enhanced proteolysis measurably in our system was $5 \mu \mathrm{M}$. This is approximately two orders higher than is likely to occur in tissues. However, factors of time and local concentrations (of hormone, proteolytic enzyme, and of specific sensitive substrates) may provide suitable conditions for physiologic effects.

As a result of these studies, certain historical observations concerning the use of iodides appear to have a scientific basis. The use of iodides for dissolving syphilitic gummas, and the fear of using iodides in tuberculosis because of the possibility of breaking down tubercles and spreading the infection, could both be related to the proteolytic action resulting from iodides in exudates. In 1915, Jobling and Petersen (11) investigated the action of iodides on necrotic material and concluded that iodides acted to soften tubercles and syphilitic gummas by causing a general reduction in antitryptic activity, thereby allowing the proteolytic breakdown of the caseous material. These early studies closely parallel our own, but we found no evidence for the implication of a protease inhibitor. Indeed, we have demonstrated that boiled sputum lacks an inhibitor of trypsin, but nevertheless its proteolysis by trypsin is enhanced in the presence of organic iodides. Our experiments suggest that the iodides interact with the substrate to produce enhanced susceptibility to proteolytic enzymes.

The highly effective action of iodinated-tyrosine compounds upon the induction of proteolysis within purulent sputum (or other purulent material) suggests that such compounds may become important therapeutic adjuncts in the treatment of chronic respiratory disease by aiding in the liquefaction of viscid respiratory secretions. We have observed that whole sputum from patients with cystic fibrosis is liquefied when mixed with DIT in vitro, indicating that a reduction in viscosity accompanies proteolysis. Compounds such as monoiodotyrosine and diiodotyrosine, in contrast to the iodinated thyronines, have no systemic calorigenic effect and may be found useful for thinning respiratory secretions without causing calorigenic side effects. The clinical effective- 
ness of such compounds, when administered by aerosol, is now being investigated.

\section{Summary}

Iodides were found to induce proteolysis in purulent sputum from patients with cystic fibrosis and other forms of respiratory disease. Proteolysis was shown to be enzymatic in nature and to depend upon the presence of natural leukocytic proteases or an added protease such as trypsin. The reaction was inhibited by conditions that inhibited the proteolytic enzyme. Naturally occurring iodinated thyroidal compounds were much more effective for inducing proteolysis than were the inorganic iodides. The $\mathrm{L}$-isomers of these thyroidal compounds promoted a higher rate of proteolysis than did the $\mathrm{D}$-isomers, when intact cells were present in the sputum preparation.

The question is raised as to whether thyroxine and its precursors affect proteolysis in vivo in cellular metabolism. The possible clinical use of iodinated tyrosine compounds is suggested for thinning viscid purulent respiratory secretions.

\section{Acknowledgment}

We are indebted to Mrs. Betty M. Trimmer for her skilled technical assistance.

\section{References}

1. Goodman, L., and A. Gilman. The Pharmacological Basis of Therapeutics, 2nd ed. New York, Macmillan, 1955 , p. 817.

2. Opie, E. L. The enzymes in phagocytic cells of inflammatory exudates. J. exp. Med. 1906, 8, 410.

3. Lieberman, J., and N. B. Kurnick. Characterization of the proteolytic activities in purulent sputum. Submitted for publication.

4. Lieberman, J., and N. B. Kurnick. Proteolytic enzyme activity and the role of deoxyribonucleic acid in cystic fibrosis sputum. Pediatrics 1963, 31, 1028.

5. Lieberman, J., and N. B. Kurnick. Influence of deoxyribonucleic acid content on the proteolysis of sputum and pus. Nature (Lond.) 1962, 196, 988.

6. Moore, S., and W. H. Stein. Photometric Ninhydrin method for use in the chromatography of amino acids. J. biol. Chem. 1948, 176, 367.

7. Lieberman, J. Enzymatic dissolution of pulmonary secretions. Amer. J. Dis. Child. 1962, 104, 342.

8. Barker, S. B. Biochemistry in The Thyroid, 2nd ed., S. C. Werner, Ed. New York, Harper \& Row, 1962, p. 102.

9. Barker, S. B. Mechanism of action of the thyroid hormone. Physiol. Rev. 1951, 31, 205.

10. Barker, S. B. In vitro action of thyroxine analogs on succinate and malate oxidation. Endocrinology 1957, 61, 534.

11. Jobling, J. W., and W. Petersen. The therapeutic action of iodin. Arch. intern. Med. 1915, 15, 286. 